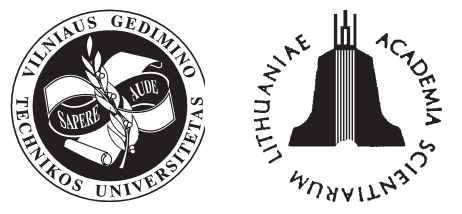

\title{
ANNUAL AVERAGE DAILY TRAFFIC FORECASTING USING DIFFERENT TECHNIQUES
}

\author{
Tomas Šliupas \\ Transport and Road Research Institute, I. Kantog.25 Kaunas.E-mail: t.sliupas@tkti.lt
}

Received 23 November 2005; accepted 4 January 2006

\begin{abstract}
This paper describes annual average daily traffic (AADT) forecasting for the Lithuanian highways using a forecasting method used by Idaho Department for Transportation, growth factor, linear regression and multiple regression. AADT forecasts obtained using these methods are compared with the forecasts evaluated by traffic experts and given in references. The results show that the best Lithuanian traffic data are obtained using Idaho forecasting method. It is assumed that the curve of AADT change should be exponential in the future.
\end{abstract}

Keywords: AADT, AADT forecasting, AADT forecasting using linear regression, AADT forecasting using multiple regression, AADT forecasting using growth factor.

\section{Introduction}

Average annual daily traffic (AADT) defines the number of vehicles crossing a road section per day. AADT measurements are performed constantly and forecasts of AADT value are being done. AADT intensity forecasts are used to plan road reconstruction, to determine what kind of upkeep and maintenance work should be done when investments into road infrastructure will bring profit and to determine how busy road traffic will be in the future.

The level of AADT value can be influenced by a number of factors, some of which can't be easily evaluated. These factors are: AADT variation in the past, changes in the economy, changes in the number of vehicles and citizens, average distance covered by a vehicle, changes in the situation of urban and industry areas, fuel prices etc. All these factors make forecasting complicated.

There were a few attempts to make AADT intensity forecasts in Lithuania. One of them included AADT forecasts on the Lithuanian highway and state roads for 2005-2025 interval [1]. These forecasts were built based on forecasts of average distance, covered by one vehicle, gross domestic product (GDP) forecasts, number of citizens change forecasts, number of vehicles in the country change forecasts, changes in the situation of urban areas, development of transport corridors and AADT value change in each road section during 1995-2004.

In this paper we will present AADT value fore- casts using different techniques used abroad. Average AADT value for the Lithuanian highway road class will be used in forecasting. Average AADT value for road class will permit us to reduce AADT measurement error. Forecasting data used are displayed in Table 1 [1-10].

Table 1. Change of AADT average for the Lithuanian highways during 1994-2004

\begin{tabular}{|c|c|c}
\hline Year & AADT, auto/day & $\begin{array}{c}\text { Highways used in } \\
\text { calculation }\end{array}$ \\
\hline 1994 & 3793 & - \\
\hline 1995 & 3837 & $\mathrm{~A} 1-\mathrm{A} 13$ \\
\hline 1996 & 4477 & $\mathrm{~A} 1-\mathrm{A} 13$ \\
\hline 1997 & 4904 & $\mathrm{~A} 1-\mathrm{A} 13$ \\
\hline 1998 & 4816 & $\mathrm{~A} 1-\mathrm{A} 13$ \\
\hline 1999 & 4674 & $\mathrm{~A} 1-\mathrm{A} 17$ \\
\hline 2000 & 4791 & $\mathrm{~A} 1-\mathrm{A} 17$ \\
\hline 2001 & 5610 & $\mathrm{~A} 1-\mathrm{A} 17$ \\
\hline 2002 & 5755 & $\mathrm{~A} 1-\mathrm{A} 17$ \\
\hline 2003 & 5971 & $\mathrm{~A} 1-\mathrm{A} 17$ \\
\hline 2004 & 5823 & $\mathrm{~A} 1-\mathrm{A} 17$ \\
\hline
\end{tabular}

\section{Practice of forecasting in Idaho, USA}

The Idaho Transportation Department uses (1) equation for AADT forecasting [11].

$$
E_{t+n}=E_{t} \times(1+g)^{n},
$$

where: $E_{t+n}-\mathrm{AADT}$ value of $t$ year, forecasted $n$ years 
in the future; $E_{t}$ - base year AADT value, observed during $t$ year; $g$ - annual AADT growth rate.

Average annual AADT growth rate is calculated using (2) equation:

$$
g=\sqrt[k]{\frac{E_{t}}{E_{t-k}}}-1,
$$

where: $k$ - a number of years between the first and the last AADT data value.

Fig 1 displays the results of using this method and the Lithuanian data (Table 1).

\section{AADT forecasting using a growth factor}

Montana Department of Transportation (USA) and some other institutions use growth factors to forecast AADT value. The method is easy to use. The method assumes that the past trends in percent increase in traffic volume each year will continue into the future. Average error of the method is approximately 28.7 percent [11]. Table 2 displays equations describing the most common types of growth. where: $E_{t}$ - base year AADT value observed during $t$ year; $a, b$ - constants.

Results of forecasting using this method and (6) equation are displayed in Fig 2.

\section{AADT forecasting, using regression}

Two types of regression will be used to forecast AADT volume:

1) linear regression;

2) multiple regression.

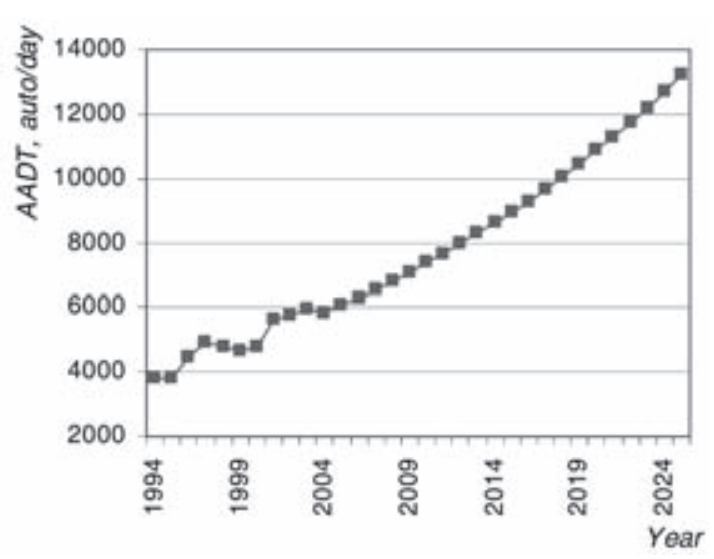

Fig 1. Forecast of average AADT value for the Lithuanian highways using a forecasting method used in Idaho, USA

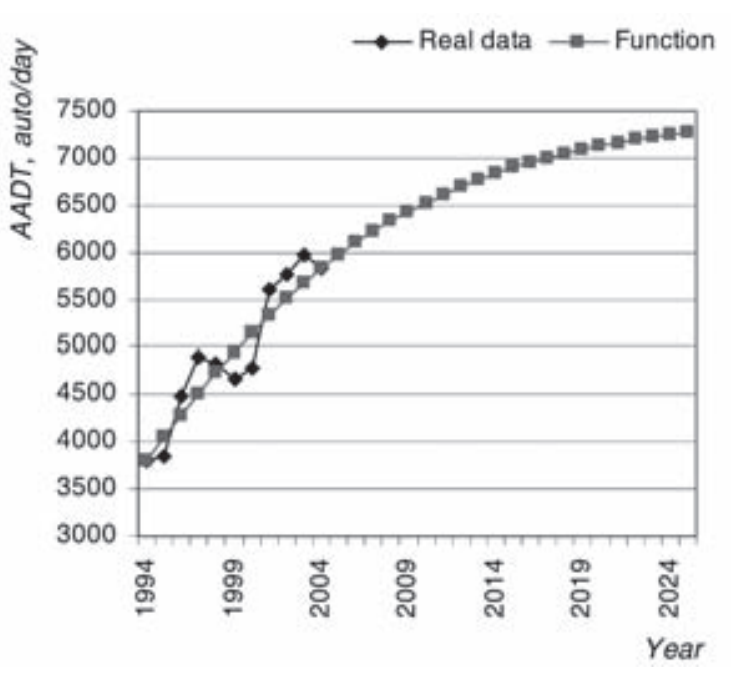

Fig 2. Forecast of average AADT value for the Lithuanian highways using a growth factor forecasting method

Table 2. The most common types of growth used in AADT forecasting method using a growth factor

\begin{tabular}{|c|c|c}
\hline No & Function & Growth rate \\
\hline$(3)$ & $\ln \left(E_{t}\right)=a+b \times t$ & $\frac{b}{(a+b \times t)}$ \\
\hline$(4)$ & $E_{t}=a+b \times t$ & $\frac{b}{2 \times(a+b \times t)}$ \\
\hline$(5)$ & $E_{t}^{2}=a+b \times t$ & $\left(\frac{-b}{10}\right) \times e^{\left(\frac{-t}{10}\right)}$ \\
\hline$(6)$ & $\ln \left(E_{t}\right)=a+b \times e^{\frac{-t}{10}}$ & $\frac{b}{t+1}$ \\
\hline$(7)$ & $\ln \left(E_{t}\right)=a+b \times[\ln (t+1)]$ & $\frac{b}{t \times[a+b \times \ln (t+1)]}$ \\
\hline$(8)$ & $E_{t}=a+b \times[\ln (t+1)]$ & \\
\hline
\end{tabular}


Using regression we can estimate the influence of economic and demographic factors on AADT.

A general example of linear regression is displayed by (9) equation.

$$
E_{t}=a_{0}+a_{1} \times X_{1 t}+\ldots+a_{n} \times X_{n t}+\varepsilon,
$$

where: $E_{t}$ - AADT value, observed during $t$ year; $X_{1 t} \ldots X_{n t}$-values of economic and demographic factors during $t$ year; $a_{0} . . a_{n}$ - constants; $\varepsilon$ - error.

We will build a linear regression function using the following economic and demographic factors:

1. gross National Product (GNP);

2. number of citizens in the country;

3. number of vehicles at the end of the year.

Table 3 displays the data describing the change of an economic and demographic factor during 19962004. received.

Equation (10) displays linear regression function

$$
\begin{aligned}
& E_{t}=105932150-0.0064 \times X_{2 t}-26.7873 \times X_{3 t} \\
& +0.0835 \times X_{1 t},
\end{aligned}
$$

where: $E_{t}-\mathrm{AADT}$ value of $t$ year; $X_{1 t}-$ GNP for one citizen in 2000 year's prices during year $t ; X_{2 t}$ - number of vehicles during year $t ; X_{3 t}$ - number of citizens during year $t$.

(10) equation's $R^{2}=0.9684$ is close to 1 . This means that the equation represents measured AADT values well, and forecasts of future values may be good too. Table 4 displays the correlation between economic and demographic factors and AADT.
As we can see from Table 4 there is negative correlation between average annual number of citizens and average AADT in highways. This means that traffic volume increases with the reduction of the number of citizens. This situation is not logical. Negative correlation is close to -1 , and it means that statistical bind between these two items is strong. Table 5 displays the prognosis of economic and demographic factors.

Forecasts obtained using linear regression (10) are displayed in Fig 3.

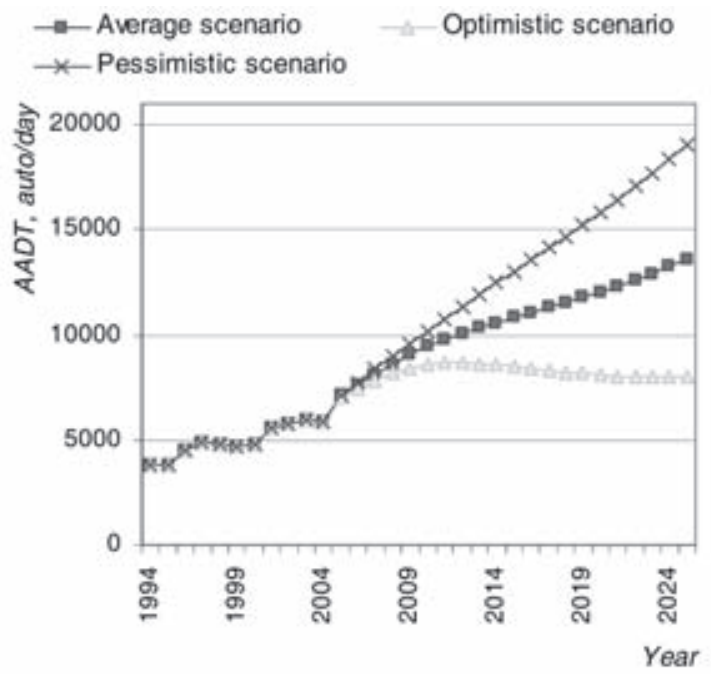

Fig 3. Forecast of average AADT value for the Lithuanian highways using linear regression

Table 3. Economic and demographic factors of Lithuania during 1996-2004 [12]

\begin{tabular}{|c|c|c|c|}
\hline Year & $\begin{array}{c}\text { GNP per citizen in 2000 year's } \\
\text { prices (Lt) }\end{array}$ & $\begin{array}{c}\text { Number of vehicles at the end of } \\
\text { the year }\end{array}$ & $\begin{array}{c}\text { Average annual number of } \\
\text { citizens (thousands) }\end{array}$ \\
\hline 1996 & 8965 & 924524 & 3601,6 \\
\hline 1997 & 11014 & 1024935 & 3575,2 \\
\hline 1998 & 12503 & 1129849 & 3549,3 \\
\hline 1999 & 12303 & 1233651 & 3524,2 \\
\hline 2000 & 13101 & 1317716 & 3499,5 \\
\hline 2001 & 13950 & 1280096 & 3481,3 \\
\hline 2002 & 14975 & 1333114 & 3469,1 \\
\hline 2003 & 16436 & 1414806 & 3454,2 \\
\hline 2004 & 18174 & 1479364 & 3435,6 \\
\hline
\end{tabular}

Table 4. Correlation between economic and demographic factors and AADT

\begin{tabular}{|l|c|c|c|}
\hline & $\begin{array}{c}\text { Number of vehicles at } \\
\text { the end of the year }\end{array}$ & $\begin{array}{c}\text { Average annual } \\
\text { number of citizens }\end{array}$ & $\begin{array}{c}\text { GNP per citizen in 2000 year's } \\
\text { prices }\end{array}$ \\
\hline Average AADT in highways & 0,86 & $-0,93$ & 0,96 \\
\hline
\end{tabular}


Table 5. Prognosis of economic and demographic factors of Lithuania [13]

\begin{tabular}{|c|c|c|c|c|c|c|c|c|c|}
\hline \multirow[b]{2}{*}{ Year } & \multicolumn{3}{|c|}{ Average scenario } & \multicolumn{3}{|c|}{ Optimistic scenario } & \multicolumn{3}{|c|}{ Pessimistic scenario } \\
\hline & $\begin{array}{c}\text { GNP per } \\
\text { citizen in } \\
2000 \text { year's } \\
\text { prices (Lt) }\end{array}$ & $\begin{array}{c}\text { Number of all } \\
\text { types of } \\
\text { vehicles at the } \\
\text { end of the } \\
\text { year }\end{array}$ & $\begin{array}{c}\text { Number } \\
\text { of citizens }\end{array}$ & $\begin{array}{c}\text { GNP per } \\
\text { citizen in } \\
2000 \text { year's } \\
\text { prices (Lt) }\end{array}$ & $\begin{array}{c}\text { Number of all } \\
\text { types of } \\
\text { vehicles at the } \\
\text { end of the year }\end{array}$ & $\begin{array}{c}\text { Number } \\
\text { of citizens }\end{array}$ & $\begin{array}{c}\text { GNP per } \\
\text { citizen in } \\
2000 \text { year's } \\
\text { prices (Lt) }\end{array}$ & \begin{tabular}{|} 
Number of all \\
types of \\
vehicles at \\
the end of the \\
year
\end{tabular} & $\begin{array}{c}\text { Number } \\
\text { of citizens }\end{array}$ \\
\hline 2005 & 18726 & 1432796 & 3406269 & 9620 & 1452532 & 3408618 & 17852 & 1416827 & 3403911 \\
\hline 2006 & 9962 & 443412 & 3387037 & 1411 & 1473600 & 3392205 & 18578 & 1418889 & 3381869 \\
\hline 2007 & 21220 & 154321 & 3368978 & 23302 & 1495481 & 3378242 & 19278 & 1420757 & 3359715 \\
\hline 2008 & 22536 & 65649 & 3352333 & 25336 & 1518383 & 3367056 & 19985 & 422503 & 3337620 \\
\hline 2009 & 911 & 5828 & 3337292 & 23 & 7 & 3358816 & 98 & & 784 \\
\hline 2010 & 25370 & 186617 & 3323953 & 29898 & 1562756 & 3353599 & 21437 & 1423974 & 3294377 \\
\hline 2011 & 26867 & 1498049 & 3312330 & 32419 & 1586885 & 3351293 & 22159 & 1424833 & 3273490 \\
\hline 2012 & 28398 & 10078 & 3302271 & 35087 & 1612252 & 3351632 & 22861 & 1425797 & 3253129 \\
\hline 2013 & 29960 & 1522622 & 3293543 & 37905 & 1638731 & 3354238 & 23540 & 1426803 & 3233142 \\
\hline 2014 & 31548 & 1535328 & 3285348 & 373 & 1665685 & 3357722 & 192 & 1427799 & 3213406 \\
\hline 2015 & & 44799 & 3277446 & & 78897 & 3361728 & 814 & 1426776 & 3193734 \\
\hline 2016 & 34782 & 1554252 & 3269641 & 47261 & 1710293 & \begin{tabular}{|l|}
3366000 \\
\end{tabular} & 25402 & 1425646 & 3174037 \\
\hline 2017 & 36417 & 1563622 & 3261793 & 50678 & 1732779 & 3370346 & 25953 & 1424356 & 3154196 \\
\hline 2018 & 38056 & 72848 & 3253778 & 54241 & 1755259 & 3374581 & 26464 & 1422876 & 3134148 \\
\hline 2019 & 39692 & 1581862 & 3245459 & 57946 & 1777648 & 3378545 & 26932 & 1421154 & 3113782 \\
\hline 2020 & 41359 & 1589798 & 3236736 & 61846 & 1798600 & \begin{tabular}{|l|l|l|}
3382110 \\
\end{tabular} & 27382 & 1418680 & 3093009 \\
\hline 2021 & 43055 & 1597414 & 3227499 & 65947 & 1819320 & \begin{tabular}{|l|l|}
3385169 \\
\end{tabular} & 27812 & 1415900 & 3071776 \\
\hline 2022 & 44777 & 1604682 & 3217705 & 70254 & 1839752 & 3387634 & 28221 & 1412774 & 3050004 \\
\hline 2023 & 46523 & 1611557 & 3207274 & 74772 & 1859852 & 3389442 & 28608 & 1409284 & 3027663 \\
\hline 2024 & 48291 & 1618033 & 3196212 & 79505 & 1879612 & 3390600 & 28971 & 1405414 & 3004726 \\
\hline 2025 & 50078 & 1624089 & 3184488 & 84459 & 1899002 & 3391075 & 29310 & 1401151 & 2981173 \\
\hline
\end{tabular}

Table 6. Multiple regression equations built using data from Table 5

\begin{tabular}{|c|l|l|}
\hline No & $R^{2}$ value & Equation \\
\hline$(11)$ & 0,9506 & $E_{t}=51389,50668+0,00001 \times X_{1 t}^{2}-0,000000003 \times X_{2 t}^{2}-0,00345 \times X_{3 t}^{2}$ \\
\hline$(12)$ & 0,9007 & $E_{t}=-63254,2+0,9 \times X_{1 t}+\frac{5748402416,7}{X_{2 t}}+\frac{219409571,1}{X_{3 t}}$ \\
\hline$(13)$ & 0,9213 & $E_{t}=792625+0,000003 \times X_{1 t}^{2}-6717,8 \times \ln \left(X_{2 t}\right)-84969,4 \times \ln \left(X_{3 t}\right)$ \\
\hline$(14)$ & 0,9623 & $E_{t}=169120,2+2313,3 \times \ln \left(X_{1 t}\right)-16,2 \times \sqrt{X_{2 t}}-2833,4 \times \sqrt{X_{3 t}}$ \\
\hline$(15)$ & 0,9579 & $E_{t}=36384,1-0,01 \times X_{2 t}+2423,6 \times \ln \left(X_{1 t}\right)-0,036 \times X_{3 t}^{2}$ \\
\hline
\end{tabular}

As we can see from Fig 3 the forecasts using pessimistic scenario are higher than the forecasts using optimistic and average scenarios. The purpose of this is negative constants in (10) equation.

Now we will build forecasts using multiple regression and the same data. Some of the multiple equations tested are displayed in Table 6.

Variables in Table 6: $E_{t}-$ AADT value of $t$ year; $X_{1 t}$ - GNP for one citizen in 2000 year's prices during year $t ; X_{2 t}$ - number of vehicles during year $t$; $X_{3 t}$ - number of citizens during year $t$.

As we can see from Table 6, the highest value of $R^{2}$ has equation no. 14 . Forecasts using this multiple regression equation are displayed in Fig 4.

As we can see from Fig 4 a pessimistic scenario has again higher value than optimistic and average scenarios. 


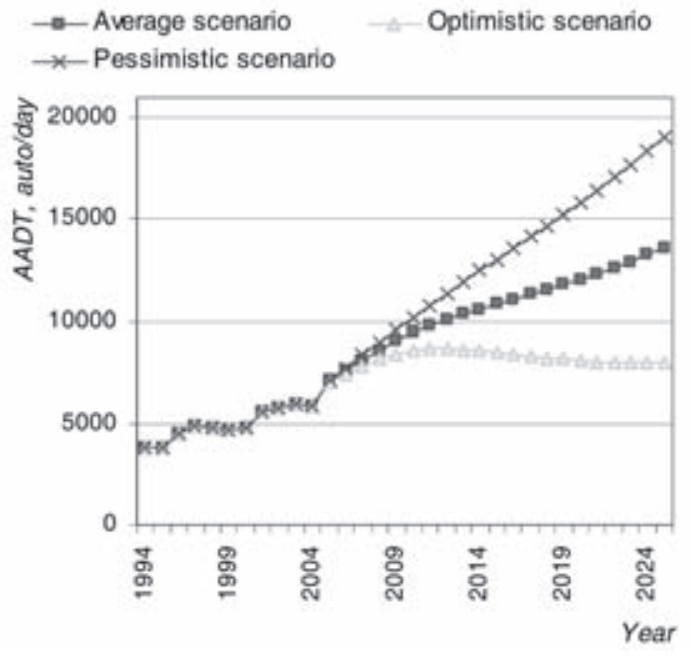

Fig 4. Forecast of average AADT value for the Lithuanian highways using multiple regression

\section{Conclusions}

Let's compare the calculated average AADT value forecasts for the Lithuanian highways [13] with forecasts obtained using here described methods (Table 7).

Forecasts from [12] references are built considering opinion of traffic experts, that's why we will compare them with other forecasts (Table 8).

Table 8 shows that the best results are obtained by Idaho method. As long as the number of citizens in Lithuania is decreasing and economy is growing, AADT value growth should decrease in the future. That's why probably the curve of AADT forecast should look like the one presented in Fig 2. Which forecast is the best, we will see in the future.

Table 7. Forecasts of AADT value for the Lithuanian highways using different methods

\begin{tabular}{|c|c|c|c|c|c|}
\hline Year & $\begin{array}{c}\text { Forecast from } \\
{[\mathbf{1 2} \text { reference }} \\
\text { source }\end{array}$ & Idaho (USA) method & Growth factor & Linear regression & $\begin{array}{c}\text { Multiple } \\
\text { regression }\end{array}$ \\
\hline 2005 & 6020 & 6054 & 5965 & 7086 & 7083 \\
\hline 2006 & 6236 & 6295 & 6097 & 7637 & 7627 \\
\hline 2007 & 6456 & 6545 & 6218 & 8156 & 8135 \\
\hline 2008 & 6682 & 6805 & 6330 & 8639 & 8605 \\
\hline 2009 & 6908 & 7076 & 6433 & 9091 & 9042 \\
\hline 2010 & 7141 & 7357 & 6528 & 9865 & 9777 \\
\hline 2011 & 7380 & 7649 & 6615 & 10185 & 10074 \\
\hline 2012 & 7625 & 7953 & 6695 & 10469 & 10330 \\
\hline 2013 & 7876 & 8269 & 6768 & 10740 & 10569 \\
\hline 2014 & 8132 & 8598 & 6835 & 11025 & 10817 \\
\hline 2015 & 8375 & 8939 & 6896 & 11309 & 11060 \\
\hline 2016 & 8622 & 9295 & 6952 & 11596 & 11300 \\
\hline 2017 & 8870 & 9664 & 7003 & 11889 & 11541 \\
\hline 2018 & 9120 & 10048 & 7049 & 12190 & 11786 \\
\hline 2019 & 9371 & 10447 & 7091 & 12513 & 12048 \\
\hline 2020 & 9620 & 10863 & 7130 & 12853 & 12322 \\
\hline 2021 & 9870 & 11294 & 7165 & 13212 & 12610 \\
\hline 2022 & 10122 & 11743 & 7197 & 13594 & 12916 \\
\hline 2023 & 10374 & 12210 & 7225 & 13996 & 13237 \\
\hline 2024 & 10627 & 12695 & 7252 & 14421 & 13577 \\
\hline 2025 & 10879 & 13199 & 7276 & & \\
\hline
\end{tabular}

Table 8. Comparison of forecasts from [12] references with forecasts obtained using other methods

\begin{tabular}{|l|c|c|}
\hline \multicolumn{1}{|c|}{ Forecasting method } & Maximum absolute error & Average absolute error \\
\hline Idaho (USA) method & $21,33 \%$ & $8,37 \%$ \\
\hline Growth factor & $33,12 \%$ & $17,27 \%$ \\
\hline Linear regression & $33,67 \%$ & $30,13 \%$ \\
\hline Multiple regression & $32,48 \%$ & $27,10 \%$ \\
\hline
\end{tabular}




\section{References}

1. Traffic intensity data preparation, research and data providing to the bank of Lithuanian roads (Eismo intensyvumo duomenu paruošimas, tyrimas ir duomenu perdavimas i Lietuvos kelių banką). Kaunas: Transport and Road Research Institute, 1996. 128 p. (in Lithuanian).

2. Transport intensity research data collection, analysis and providing of the results (Eismo intensyvumo tyrimo duomenu surinkimas, analizè ir rezultatu pateikimas). Kaunas: Transport and Road Research Institute, 1997. 127 p. (in Lithuanian).

3. Transport intensity research data collection, analysis and providing of results (Eismo intensyvumo tyrimo duomenų surinkimas, analizè ir rezultatų pateikimas). Kaunas: Transport and Road Research Institute, 1998. 74 p. (in Lithuanian).

4. Results of traffic intensity accounting during 1998 (1998 m. eismo intensyvumo apskaitos rezultatai). Kaunas: Transport and Road Research Institute, 1999. 105 p. (in Lithuanian).

5. Accounting of traffic intensity during 1999 (1999 m. eismo intensyvumo apskaita). Kaunas: Transport and Road Research Institute, 1999. 71 p. (in Lithuanian).

6. Results of traffic intensity accounting during 2000 (2000 m. eismo intensyvumo apskaitos rezultatai). Kaunas: Transport and Road Research Institute, 2001. 76 p. (in Lithuanian).

7. Vehicle traffic intensity research on state roads (Valstybiniu kelių automobilių eismo intensyvumo tyrimai). Volume 3. Kaunas: Transport and Road Research Institute, 2002. 206 p. (in Lithuanian).

8. Vehicle traffic intensity accounting, data collection improvement of accounting system and supervision (Automobilių eismo keliuose apskaita, duomenų kaupimas, jos valdymo sistemos tobulinimas ir priežiūra). Volume 1. Kaunas: Transport and Road Research Institute, 2002. 174 p. (in Lithuanian).

9. Research of traffic intensity on state roads (Eismo intensyvumo tyrimai valstybinès reikšmès keliuose). Kaunas: Transport and Road Research Institute, 2003. 315 p. (in Lithuanian).

10. Vehicle traffic data collection and upgrade of state roads (Valstybinès reikšmès kelių eismo intensyvumo duomenu kaupimas ir atnaujinimas). Volume 3. Kaunas: Transport and Road Research Institute, 2003. 204 p. (in Lithuanian).

11. Dixon, Michael. The effects of errors in annual average daily traffic forecasting: study of highways in Rural Idaho. National Institute for Advanced Transportation Technology University of Idaho, 2004. 66 p.

12. http://www.std.lt, Department for Statistics, 7 December, 2005.

13. Collection, analysis, processing and providing of TEM/ TEN - TR corridor data to international organizations (TEM/TEN - TR koridorių duomenu kaupimas, analizé, apdorojimas ir pateikimas tarptautinèms organizacijoms). Volume 2. Transport and Road Research Institute, Kaunas, 2005. 94 p. (in Lithuanian). 